\title{
PENGARUH KINERJA LINGKUNGAN, SENSITIVITAS INDUSTRI, DAN UKURAN PERUSAHAAN TERHADAP PENGUNGKAPAN CORPORATE SOCIAL RESPONSIBILITY DI PERUSAHAAN MANUFAKTUR YANG TERDAFTAR DI BURSA EFEK INDONESIA
}

\author{
Ketut Tanti Kustina* 1), Tzania Ayu Hasanah ${ }^{2)}$ \\ ${ }^{1), 2)}$ Program Studi Akuntansi Universitas Pendidikan Nasional Denpasar \\ *tantikartika16@yahoo.com
}

\begin{abstract}
Abstrak
Corporate Social Responsibility adalah bentuk tanggung jawab sosial perusahaan yang diungkapkan secara transparan dan diharapkan dapat memperoleh legistimasi dari publik. Penelitian ini bertujuan untuk mengetahui pengaruh Kinerja Lingkungan, Ukuran Perusahaan, dan Sensitivitas Industri terhadap pengungkapan Corporate Social Responsibility di Perusahaan Manufaktur yang terdaftar di Bursa Efek Indonesia tahun 2015 - 2017. Teknik pemilihan sample menggunakan purposive sampling pada 24 perusahaan manufaktur. Teknik analisis data yang digunakan dalam penelitian ini adalah uji asumsi klasik dan uji regresi linier berganda. Seluruh variabel dinyatakan bebas dari gangguan asumsi-asumsi klasik yang ada. Dari hasil uji regresi linier berganda hasil uji f diperoleh nilai signifikan 0,000 atau $<0,05$. Hal ini berarti bahwa Kinerja Lingkungan, Ukuran Perusahaan, dan Sensitivitas Industri di Perusahaan Manufaktur yang terdaftar di Bursa Efek Indonesia berpengaruh signifikan secara simultan. Pengujian secara parsial menunjukkan hasil bahwa variabel Kinerja Lingkungan dan Sensitivitas Industri berpengaruh positif dan signifikan terhadap Corporate Social Responsibility sedangkan variabel Ukuran Perusahaan mempunyai pengaruh yang negatif terhadap Corporate Social Responsibility.
\end{abstract}

Kata Kunci : Corporate Social Responsibility, Sensitivitas Industri, Ukuran Perusahaan, Kinerja Lingkungan

\begin{abstract}
Corporate Social Responsibility is a disclosed transparently and is expected to obtain legitimacy from the public. This study aims to determine the effect of Environmental Performance, Company Size, and Industry Sensitivity on the disclosure of Corporate Social Responsibility in Manufacturing Companies listed on the Indonesia Stock Exchange in 2015 - 2017. The technique of sample selection uses purposive sampling in 24 manufacturing companies. Data analysis techniques used in this study are the classic assumption test and multiple linear regression test. All variables are stated to be free from interference from classical assumptions. From the results of multiple linear regression test results $f$ test obtained a significant value of 0,000 or $<0.05$. This means that Environmental Performance, Company Size, and Industrial Sensitivity in Manufacturing Companies listed on the Indonesia Stock Exchange have a significant simultaneous effect. Partial testing shows the results that the variable Environmental Performance and Industrial Sensitivity has a positive and significant effect on Corporate Social Responsibility while the Company Size variable has a negative influence on Corporate Social Responsibility.
\end{abstract}

Keywords: Corporate Social Responsibility, Industrial Sensitivity, Company Size, Environmental Performance

\section{PENDAHULUAN}

Dewasa ini persaingan yang ketat membuat perusahaan hanya terfokus pada keuntungan dan mengesampingkan masalah lingkungan dan sosial yang ada disekitar perusahaan. Keberhasilan perusahaan bukan hanya berasal dari dari faktor internal saja tetapi juga dipengaruhi oleh masyarakat dan lingkungan karena perusahaan merupakan bagian dari masyarakat dan lingkungan. Perusahaan diharapkan berpedoman pada triple bottom line karena keseimbangan lingkungan dan masyarakat juga perlu diperhatikan sehingga keberlanjutan perusahaan dapat kelangsungannya.

Selain menimbulkan dampak positif berupa konstribusi terhadap pembangunan perekonomian, perusahaan manufaktur juga tidak terlepas dari dampak negatif mulai dari yang menyebabkan pencemaran lingkungan sampai adanya eksploitasi sumber daya dan lain sebagainya, sehingga perusahaan perlu menerapkan Corporate Social Responsibility agar aktivitas perusahaan dapat berjalan dengan selaras dan dapat berlangsungnya keberlanjutan perusahaan.

Corporate Social Responsibility (CSR) 
merupakan bentuk pertanggungjawaban yang dilakukan perusahaan terhadap sosial dan lingkungan seperti meningkatkan kesejahteraan masyarakat dan lingkungan dalam rangka meningkatkan kualitas sumber daya manusia di sekitar wilayah aktivitas perusahaan itu berada. CSR mengungkapkan keagiatan sosial yang dilakukan oleh perusahaan secara tranparansi dimana informasi yang diungkapkan tidak hanya informasi keuangan perusahaan saja tetapi informasi mengenai dampak sosial dan lingkungan hidup yang diakibatkan aktivitas perusahaan juga diharapkan dapat diungkapkan. "Undang-Undang Nomor. 40 Tahun 2007 tentang Perseroan Terbatas mewajibkan perusahaan yang beroperasi dibidang eksplorasi sumber daya alam seperti pertambangan dan manufaktur, selain itu maka pelaksanaan CSR bersifat sukarela". Alasan perusahaan menerapkan CSR adalah untuk membentuk katup pengaman sosial (social security). Selain itu melalui CSR seperti meningkatkan citra perusahaan maupun pemegan sahamnya, posisi merek perusahaan maupun bidang usaha perusahaan (Basalamah \& Jermias, 2005).

Kinerja lingkungan merupakan kinerja perusahaan dalam menciptakan lingkungan yang ramah lingkungan dengan berkontribusi memelihara sumber daya alam. Perusahaan yang memiliki kinerja yang baik merupakan goodnews bagi stakeholder. Kinerja lingkungan merupakan usaha perusahaan dalam menciptakan lingkungan yang ramah lingkungan. Program Penilaian Peringkat Kinerja Perusahaan (PROPER) merupakan salah satu upaya Kementerian Negara Lingkungan Hidup untuk mendorong penaatan perusahaan dalam pengelolaan lingkungan hidup melalui instrumen informasi. Dilakukan melalui berbagai kegiatan yang diarahkan untuk: (i) mendorong perusahaan untuk menaati peraturan perundang-undangan melalui insentif dan disinsentif reputasi, dan (ii) mendorong perusahaan yang sudah baik kinerja lingkungannya untuk menerapkan produksi bersih (cleaner production). Penelitian yang dilakukan oleh Sari, Yuliandari, \& Nurbaiti, (2017) menunjukkan bahwa PROPER mendorong perusahaan untuk selalu melaksanakan peningkatan kinerja lingkungan sehingga memperoleh apresiasi.Berbeda dengan Sukasih \& Sugiyanto, (2017) menyatakan bahwa kinerja lingkungan yang diukur dengan peringkat PROPER tidak berpengaruh signifikan terhadap perusahaan juga dapat membangun reputasinya,

diungkapkan perusahaan tidak banyak diungkapkan dilaporan tahunan.

Sensitivitas industri diartikan sebagai perusahaan yang memiliki tingkat sensitivitas industri tinggi akan memperoleh perhatian yang lebih dari masyarakat dan kepentingan lain karena aktivitas industri yang berpotensi mempengaruhi kepentingan luas, baik dari segi ekonomi, sosial dan lingkungan (Anggraini, 2006). Industri highprofile merupakan perusahaan yang memiliki tingkat kepekaan yang tinggi karena diyakini melakukan pengungkapan pertanggungjawaban sosial yang lebih dan akan memperoleh sorotan dari masyarakat. Penelitian yang dilakukan oleh Widiastuti, Utami, \& Handoko, (2018) menyatakan bahwa tipe industri berpengaruh positif signifikan terhadap pengungkapan tanggung jawab sosial karena pengaruh tipe industri terhadap pengungkapan tanggung jawab sosial menunjukkan bahwa perusahaan high profile mempunyai banyak sorotan karena terlibat dengan berbagai macam pemangku kepentingan sehingga pengungkapan sebagai alat komunikasi yang efektif. Penelitian yang dilakukan Harsono, Handoko, \& Fransisca, (2012) tipe industri tidak berpengaruh signifiikan terhadap tingkat pengungkapan tanggung jawab sosial karena tekanan dari para aktivis sosial dan lingkungan, serta pengawasan oleh pemerintah tidak hanya berpusat pada perusahaan dengan jenis industri tertentu.

Ukuran Perusahaan merupakan bentuk pengklasifikasian besar kecilnya skala perusahaan. Perusahaan dengan skala besar biasanya akan lebih mudah dalam melakukan pengungkapan tanggung jawab sosial dikarenakan perusahaan besar memiliki jumlah assets yang lebih besar di banding dengan perusahaan yang masih berskala kecil (Sembiring, 2006). Di samping itu, perusahaan berskala kecil lebih terfokus untuk meningkatkan jumlah aset perusahaan dan meningkatkan hasil penjualan dibandingkan melakukan pengungkapan CSR. Perusahaan besar akan mengungkapkan informasi lebih luas karena memiliki public demand. Penelitian yang dilakukan Widiastuti et al., (2018) ukuran perusahaan berpengaruh signifikan dan positif terhadap pengungkapan CSR karena semakin besar ukuran perusahaan maka aktivitas yang dilakukan oleh perusahaan juga semakin banyak sehingga pengungkapan aktivitas perusahaan semakin luas. Penelitian Harsono et al., (2012) menyatakan hasil yang berbeda yaitu ukuran perusahaan tidak hernengaruh sionifikan Jurnal KRISNA: Kumpulan Riset Akuntansi Volume 11, Nomor 22020 CC-BY-SA 4.0 License

Page 114 
terhadap tingkat pengungkapan tanggung jawab sosial karena ukuran perusahaan bukan merupakan faktor yang menjadi pertimbangan bagi perusahaan

\section{TINJAUAN PUSTAKA Teori Legitimasi}

Legitimasi masyarakat merupakan wahana untuk mengonstruksi strategi perusahaan, terutama terkait dengan upaya memposisikan diri ditengah lingkungan masyarakat yang semakin maju (Hadi, 2011). Oleh karena itu dibutuhkannya interaksi dan dukungan masyarakat yang sejalan dengan norma sosial sehingga aktivitas perusahaan dapat berjalan dengan selaras dan berkelanjutan.

\section{Kinerja Lingkunngan}

Kinerja lingkungan perusahaan merupakan usaha perusahaan dalam menciptakan lingkungan yang green (Suratno, Darsono, \& Mutmainah, 2007). Program Penilaian Peringkat Kinerja Perusahaan (PROPER) digunakan untuk mengukur kinerja lingkungan yang berlandaskan atas Keputusan Menteri Negara Lingkungan Hidup Nomor : 250 tahun 2004. Peringkat kinerja PROPER menggunakan indikator warna, dimulai dari yang terbaik, emas $=$ sangat - sangat baik $=5$, hijau $=$ sangat baik $=4$, biru $=$ baik $=3$, merah $=$ buruk $=2$, sampai ke terburuk diindikasikan dengan warna hitam $=1$. Diadakannya program ini agar perusahaan terdorong untuk meningkatkan kuantitas tranparansi aktivitas pengelolaan lingkungan perusahaan.

\section{Sensitivitas Industri}

Perbedaan jenis industri menghasilkan tingkat sensitivitas yang berbeda karena pengaruh yang dihasilkan tidak sama. Sensitivitas industri diproksikan dengan tipe industri dan dapat diukur dengan dengan variabel dummy. Perusahaan high profile merupakan perusahaan yang memiliki tingkat kepekaan tinggi dan dianggap melakukan tanggung jawab sosial lebih luas yang akan berdampak terhadap masyarakat dan memiliki visibilitas konsumen, risiko politis yang tinggi, atau menghadapi persaingan yang tinggi dalam (Anggraini, 2006). Oleh karena itu, pengungkapan tanggung jawab sosial yang lebih merupakan bentuk legitimasi atas kegiatan operasinya. Pada saat ini, perusahaan dalam industri profil tinggi, meliputi: pertanian, kehutanan, perikanan, pertambangan dan jasa penambangan, konstruksi, makanan dan minuman, produsen tembakau, kertas dan produk bersekutu, kimia dan produk bersekutu, plastik dan produk kaca, otomotif dan bersekutu nroduk farmasi harano konsumsi telekomunikasi dalam memutuskan tanggung jawab sosial.

tingkat

pengungkapan

Sedangkan perusahaan dalam industri low profile, meliputi: pakan ternak dan peternakan, produk pabrik tekstil, pakaian jadi dan produk tekstil lainnya, kayu dan produk kayu, perekat, semen, logam dan produk serumpun, produk logam fabrikasi, batu, tanah liat, kaca, dan beton produk, kabel, peralatan elektronik dan kantor, peralatan fotografi, layanan transportasi, perdagangan grosir dan ritel, perbankan, agen kredit selain bank, sekuritas, asuransi, real estat dan properti, hotel dan jasa perjalanan, holding dan perusahaan investasi lainnya, dan lainnya (Harsono et al., 2012).

\section{Ukuran Perusahaan}

Ukuran perusahaan merupakan bentuk pengklasifikasian besar kecilnya skala perusahaan. Menurut Cowen dalam (Nur \& Priantinah, 2012) menyatakan bahwa teori legitimasi memiliki alasan tentang hubungan ukuran perusahaan dan pengungkapan. Perusahaan besar cenderung memiliki resiko kerusakan lingkungan sosial yang lebih besar sehingga perusahaan besar terdorong untuk melakukan legitimasi dengan mengungkapkan informasi yang lebih dibandingkan perusahaan kecil. Selain itu, ukuran perusahaan dapat menentukan tingkat kepercayaan investor karena semakin besar ukuran sebuah perusahaan, maka perusahaan akan semakin dikenal oleh masyarakat dan memiliki public demand yang tinggi sehingga dilakukannya pengungkapan yang lebih besar dengan harapan dapat mengurangi biaya politis. Ukuran sebuah perusahaan dapat diukur dengan total aset, jumlah tenaga kerja, total penjualan, rata - rata tingkat penjualan dan kapitalisasi pasar. Total aset dinilai lebih valid dan tidak dipengaruhi pasar dibanding proksi lain.

\section{Corporate Social Responsibility}

Menurut The World Business Council for Sustainable Development (WBCSD) mendefinisikan CSR sebagai bentuk tindakan etis perusahaan yang diarahkan untuk meningkatkan ekonomi dan kualitas hidup baik karyawan dan keluarganya serta masyarakat sekitar dan masyarakat lebih luas (Hadi, 2011). CSR yang diterapkan secara konsisten akan mampu memperbaiki dan mempererat hubungan yang berkelanjutan antara perusahaan dengan para stakeholder-nya Perwsahaan diharapkan juga_dapat Jurnal KRISNA: Kumpulan Riset Akuntansi Volume 11, Nomor 22020 CC-BY-SA 4.0 License

Page 115 
mengungkapkan informasi atas aktivitas perusahaan mengenai dampak lingkungan akibat dari kegiatan operasi dan peran perusahaan dalam meningkatkan kualitas lingkungan secara transparan. "Undang-Undang Nomor 40 Tahun 2007 tentang Perseroan Terbatas mewajibkan perusahaan yang beroperasi dibidang eksplorasi sumber daya alam seperti pertambangan dan manufaktur, selain itu maka pelaksanaan CSR bersifat sukarela". Berdasarkan GRI G4 mengelompokkan informasi pengungkapan CSR kedalam 3 (tiga) kategori pengungkapan yaitu: (1) Ekonomi, (2) Lingkungan, dan (3) Sosial dengan sub-kategori ketenagakerjaan, HAM, masyarakat dan tanggungjawab produk. Masing-masing kategori tersebut memiliki item-item yang keseluruhannya berjumlah 91 item. CSR memiliki konsep 3P (profit, people, planet) dimana tujuan dari perusahaan tidak hanya keuntungan ekonomi tetapi juga peduli terhadap kesejahteraan manusia dan lingkungan hidup.

Kerangka Pemikiran

Corporate Social Responsibility merupakan tindakan etis berupa bentuk pertanggungjawaban yang dilakukan perusahaan. Adanya dorongan untuk mendapatkan legitimasi dari masyarakat maka perusahaan menerapkan CSR sehingga diharapkan perusahaan mampu menghasilkan laporan kinerja perusahaan baik finansial maupun pengungkapan sosial secara transparan. CSR dapat membentuk katup pengaman sosial seperti. membangun reputasi perusahaan. Sensitivitas industri merupakan perusahaan yang memiliki tingkat kepekaan yang tinggi karena memiliki sorotan dari masyarakat akibat potensi yang dimiliki perusahaan dalam beroperasi yang memiliki dampak baik dari segi ekonomi maupun sosial sehingga perusahaan melakukan pengungkapan pertanggungjawaban sosial yang lebih. Ukuran perusahaan adalah bentuk pengklasifikasian besar kecilnya skala suatu perusahaan. Perusahaan besar akan melakukan pengungkapan sosial lebih luas sebagai bentuk legitimasi atas aktivitas perusahaan yang akan menghasilkan dampak dan resiko yang lebih besar terhadap kerusakan lingkungan sehingga perusahaan akan menerapkan CSR. Selain itu, Kinerja lingkungan merupakan kinerja perusahaan dalam menciptakan lingkungan yang ramah lingkungan dan dapat melestarikan sumber daya alam. Adanya penilaian peringkat dengan PROPER akan membuat perusahaan termotivasi untuk meningkatkan kualitas dan kuantitas informasi tanggung jawab sosialnya.

\section{Gambar 2.1}

Kerangka Berpikir

Pengaruh Kinerja Lingkungan, Sensitivitas Industri, dan Ukuran Perusahaan, Terhadap Corporate Social Responsibility Di Perusahaan Manufaktur Yang Terdaftar Di Bursa Efek Indonesia

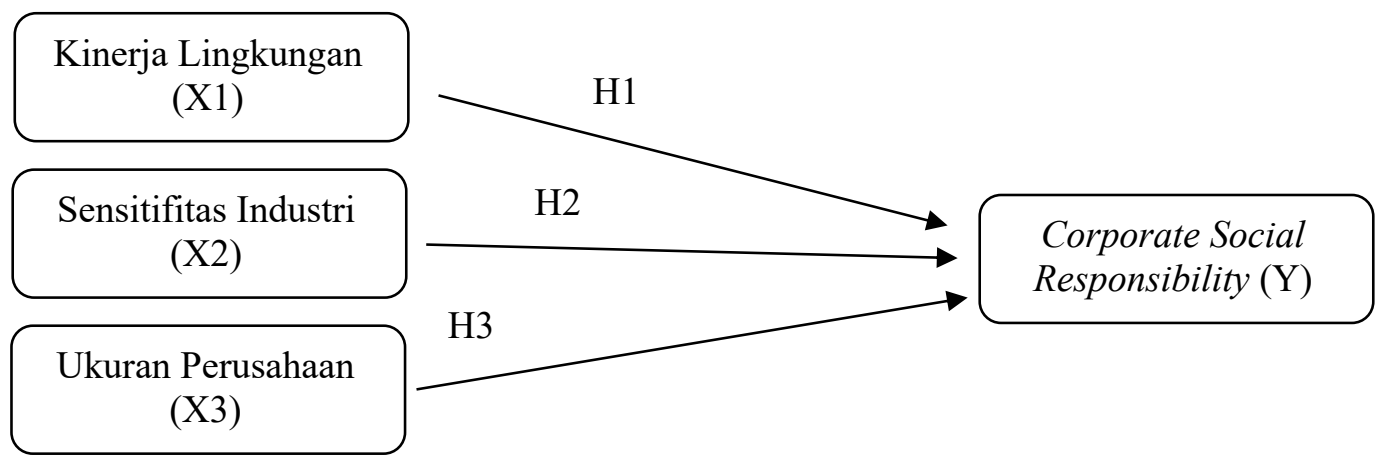


Pengungkapan Corporate Social Responsibility

Kinerja lingkungan merupakan bentuk usaha perusahaan dalam menciptakan lingkungan yang ramah lingkungan. Perusahaan dengan kinerja lingkungan yang baik perlu mengungkapkan informasi kuantitas dan mutu lingkungan yang lebih dibandingkan dengan perusahaan dengan kinerja lingkungan yang lebih buruk (Wijaya, 2012). Perusahaan harus mampu membuat masyarakat percaya bahwa perusahaan dapat menjaga kelestarian lingkungan dan beroperasi dengan baik tanpa adanya pihak yang dirugikan. Semakin banyak peran perusahaan dalam kegiatan lingkungannya, maka akan semakin banyak pula yang harus diungkapkan oleh perusahaan mengenai kinerja lingkungan yang dilakukannya dalam laporan tahunannya (Sukasih \& Sugiyanto, 2017). Perusahaan dengan kinerja lingkungan yang baik akan menghasilkan respon positif yang bermanfaat bagi keberlanjutan perusahaan.

$\mathbf{H}_{1}$ : Kinerja Lingkungan berpengaruh positif terhadap CSR di perusahaan manufaktur yang terdaftar di Bursa Efek Indonesia.

\section{Pengaruh Sensitivitas Industri terhadap Pengungkapan Corporate Social Responsibility}

Sensitivis industri menandakan kegiatan operasi perusahaan dan dampaknya terhadap lingkungan dan sosial. Zulaikha \& Setyawan (2012) menyatakan bahwa sensitivitas industri berpengaruh signifikan terhadap pengungkapan tanggung jawab sosial dikarenakan perusahaan yang memiliki kepekaan tinggi mempunyai dampak potensi yang lebih tinggi dalam memengaruhi kondisi serta keberadaan lingkungan. Perhatian lebih yang timbul dari masyarakat akan mempengaruhi banyaknya pengungkapan informasi sosial yang dilakukan

\section{METODE PENELITIAN Definisi Operasional Variabel Bebas (Variabel Independen) \\ a. Sensitivitas Industri}

Sensitivitas industri merupakan karakteristik yang dimiliki perusahaan manufaktur yang berkaitan dengan bidang usaha, risiko usaha, karyawan yang dimiliki dan lingkungan perusahaan. Sensitivitas industri diukur dengan menggunakan variabel dummy. Nilai 1 untuk perusahaan kategori high profil. Nilai 0 untuk perusahaan kategori low profile.

b. Ukuran Perusahaan

Ukuran Perusahaan menggambarkan besar kecilnva suatu nerusahaan manufaktur vano danat perusahaan. Industri high profile memunculkan lebih banyak dampak sosial dibanding industri low profile sehingga mereka melaksanakan tanggung jawab sosial dan mengungkapkannya sebagai bentuk legitimasi atas kegiatan operasi perusahaan (Mirfazli \& Nurdiono, 2007). Legitimasi yang didapatkan perusahaan diharapkan dapat menurunkan tekanan dari para aktivis.

$\mathbf{H}_{2}$ : Sensitivitas Industri berpengaruh positif terhadap CSR di perusahaan manufaktur yang terdaftar di Bursa Efek Indonesia.

\section{Pengaruh Ukuran Perusahaan terhadap Corporate Social Responsibility}

Perusahaan besar akan lebih mendapatkan banyak sorotan dari kepentingan luas dan cenderung memiliki public demand. Dengan mengungkapkan kepedulian pada lingkungan melalui pelaporan keuangan, maka perusahaan dalam jangka waktu panjang bisa terhindar dari biaya yang sangat besar akibat dari tuntutan masyarakat (Amelia \& Cahyati, 2015). Perusahaan besar cenderung mengungkapkan informasi yang lebih dibandingkan perusahaan kecil karena melakukan aktivitas yang lebih banyak. Semakin besar ukuran sebuah perusahaan, maka perusahaan tersebut akan semakin dikenal oleh masyarakat, hal ini berarti bahwa kesempatan untuk mendapatkan informasi mengenai perusahaan akan menjadi semakin mudah (Respati \& Hadiprajitno, 2015). Oleh karena itu, ukuran perusahaan dapat menentukan tingkat kepercayaan investor dengan berdasarkan kuantitas informasi yang diungkapkan.

H2: Ukuran Perusahaan berpengaruh positif terhadap CSR di perusahaan manufaktur yang terdaftar di Bursa Efek Indonesia

diproksikan dengan total aset perusahaan karena dinilai lebih valid dan tidak terpengaruh oleh pasar dibanding proksi lain. Ukuran perusahaan diukur berdasarkan logaritma natural dari total aset perusahaan

Ukuran Perusahaan $=$ Log total aset

c. Kinerja Lingkungan

Kinerja lingkungan adalah usaha perusahaan dalam menciptakan lingkungan yang baik dengan menggunakan bahan - bahan yang ramah lingkungan. Kinerja lingkungan perusahaan diukur dengan menggunakan skala ordinal dari penilaian PROPER karena merupakan program unggulan KLH yang hukumnya wajib bagi perusahaan karena ditetapkan oleh pemerintah. PROPER 
memberikan skor untuk masing-masing warna, yakni: Emas $=5$, Hijau $=4$, Biru $=3$, Merah $=2$, Hitam $=1$.

\section{Variabel Terikat (Variabel Dependen)}

Pengungkapan CSR merupakan pengungkapan informasi yang berkaitan dengan dampak lingkungan akibat dari kegiatan operasi dan peran perusahaan dalam meningkatkan kualitas lingkungan di dalam laporan tahunan perusahaan manufaktur. CSR diukur dengan Corporate Social Responsibility Index (CSRI) yang berpedoman pada instrumen Global Instrument Initiative (GRI) versi GRI G4 karena dianggap lebih relevan dengan objek penelitian. Penghitungan CSR menggunakan pendekatan dikotomi, yaitu setiap kategori informasi pengungkapan CSR dalam instrumen penelitian diberi skor 1 jika diungkapkan, dan nilai 0 jika tidak diungkapkan. Selanjutnya, skor dari setiap item dijumlahkan untuk memperoleh keseluruhan skor setiap perusahaan. Data skor CSR tersebut akan dinyatakan dengan satuan persen (\%).

Pengungkapan CSR dihitung dengasn rumus sebagai berikut;

$$
\mathrm{CSRI}=\sum_{N y} \mathrm{Xky} \quad \mathrm{x} 100 \%
$$

Keterangan :

CSRly : Corporate Social Responsibility Index perusahaan $\mathrm{y}$. diungkapkan dalam laporan tahunan, $0=$ kategori informasi tidak diungkapkan.

Ny : jumlah item untuk perusahaan y.

\section{Definisi Operasional}

\section{Variabel Bebas (Variabel Independen)}

a. Sensitivitas Industri

Sensitivitas industri merupakan karakteristik yang dimiliki perusahaan manufaktur yang berkaitan dengan bidang usaha, risiko usaha, karyawan yang dimiliki dan lingkungan perusahaan. Sensitivitas industri diukur dengan menggunakan variabel dummy. Nilai 1 untuk perusahaan kategori high profil. Nilai 0 untuk perusahaan kategori low profile.

b. Ukuran Perusahaan

Ukuran Perusahaan menggambarkan besar kecilnya suatu perusahaan manufaktur yang dapat diproksikan dengan total aset perusahaan karena dinilai lebih valid dan tidak terpengaruh oleh pasar dibanding proksi lain. Ukuran perusahaan diukur berdasarkan logaritma natural dari total aset perusahaan

Ukuran Perusahaan $=$ Log total aset $\sum$ Xky: total dari $1=$ kategori informasi

c. Kinerja Lingkungan

Kinerja lingkungan adalah usaha perusahaan dalam menciptakan lingkungan yang baik dengan menggunakan bahan - bahan yang ramah lingkungan. Kinerja lingkungan perusahaan diukur dengan menggunakan skala ordinal dari penilaian PROPER karena merupakan program unggulan KLH yang hukumnya wajib bagi perusahaan karena ditetapkan oleh pemerintah. PROPER memberikan skor untuk masing-masing warna, yakni: Emas $=5$, Hijau $=4$, Biru $=3$, Merah $=2$, Hitam $=1$.

\section{Variabel Terikat (Variabel Dependen)}

Pengungkapan CSR merupakan pengungkapan informasi yang berkaitan dengan dampak lingkungan akibat dari kegiatan operasi dan peran perusahaan dalam meningkatkan kualitas lingkungan di dalam laporan tahunan perusahaan manufaktur. CSR diukur dengan Corporate Social Responsibility Index (CSRI) yang berpedoman pada instrumen Global Instrument Initiative (GRI) versi GRI G4 karena dianggap lebih relevan dengan objek penelitian. Penghitungan CSR menggunakan pendekatan dikotomi, yaitu setiap kategori informasi pengungkapan CSR dalam instrumen penelitian diberi skor 1 jika diungkapkan, dan nilai 0 jika tidak diungkapkan. Selanjutnya, skor dari setiap item dijumlahkan untuk memperoleh keseluruhan skor setiap perusahaan. Data skor CSR tersebut akan dinyatakan dengan satuan persen $(\%)$.

Pengungkapan CSR dihitung dengasn rumus sebagai berikut;

$$
\mathrm{CSRI}=\sum_{N y} \mathrm{Xky} \quad \mathrm{x} \underline{100 \%}
$$

Keterangan :

CSRly : Corporate Social Responsibility Index perusahaan $\mathrm{y}$.

$\sum X k y:$ total dari $1=$ kategori informasi diungkapkan dalam laporan tahunan, $0=$ kategori informasi tidak diungkapkan.

Ny : jumlah item untuk perusahaan y.

Penelitian ini dilakukan pada perusahaan manufaktur yang terdaftar di Bursa Efek Indonesia (BEI). Jenis data yang digunakan adalah data kuantitatif. Sumber data yang digunakan adalah data sekunder dengan jenis data kuantitatif. Populasi pada penelitian ini adalah perusahaan manufaktur yang terdaftar di Bursa Efek Indonesia pada tahun 2015 - 2017 yaitu sebanyak 144 perusahaan Pemilihan sampel penelitian didasarkan pada metode purposive sampling. 
Sample penelitian yang digunakan 24 perusahaan manufaktur yang dipilih menggunakan metode pemilihan sampel adalah purposive sampling, yaitu dengan mengkategorikan perusahaan berdasarkan kriteria sebagai berikut :

Tabel 3.1

Proses Pemilihan Sampel

\begin{tabular}{c|c|c}
\hline No & Kriteria & Jumlah \\
\hline 1 & $\begin{array}{c}\text { Perusahaan manufaktur yang terdafatar di Bursa Efek } \\
\text { Indonesia pada tahun 2015-2017 }\end{array}$ & 144 \\
\hline 2 & $\begin{array}{c}\text { Perusahaan manufaktur yang telah mengikuti Program } \\
\text { Penilaian Peringkat Kinerja Perusahaan dalam Pengelolaan } \\
\text { Lingkungan Hidup (PROPER) selama periode 2015-2017 }\end{array}$ & 53 \\
\hline 3 & $\begin{array}{c}\text { Perusahaan manufaktur yang menerbitkan laporan keuangan } \\
\text { dan laporan tahunan berturut - turut tahun 2015 - 2017 dalam } \\
\text { satuan mata uang Rupiah }\end{array}$ & 42 \\
\hline 4 & Perusahaan manufaktur yang tidak mengalami kerugian & 33 \\
\hline 5 & $\begin{array}{c}\text { Perusahaan yang menyediakan informasi lengkap mengenai } \\
\text { pelaksanaan CSR selama periode 2015-2017 }\end{array}$ & 24 \\
\hline & \begin{tabular}{c} 
Total Sampel \\
\hline
\end{tabular} & 24
\end{tabular}

Teknik analisis yang digunakan adalah analisis regresi linear berganda. Data yang dikumpulkan akan secara bertahap dianalisis mulai dari analisis statistik deskriptif, uji asumsi klasik yang terdiri dari uji nomalitas, uji multikolinearitas, uji autokorelasi, uji heteroskestisitas, Uji Kelayakan Model yang terdiri dari Uji $\mathrm{R}^{2}$ dan Uji F, dan uji hipotesis yaitu Uji $\mathrm{T}$ untuk mengetahui apakah hipotesis yang sedang diuji ditolak atau diterima.

\section{HASIL DAN PEMBAHASAN}

\section{Statistik Deskriptif}

Tabel 1.

Descriptive Statistics

\begin{tabular}{cccccccc}
\hline & $\mathrm{N}$ & Minimum & Maximum & Sum & Mean & Std. Deviation Variance \\
\hline $\mathrm{Y}$ & 72 & .18 & .54 & 23.72 & .3294 & .08819 & .008 \\
\hline $\mathrm{X} 3$ & 72 & .00 & 1.00 & 39.00 & .5417 & .50176 & .252 \\
\hline $\mathrm{X} 3$ & 72 & 2.00 & 5.00 & 231.00 & 3.2083 & .50176 & .252 \\
\hline $\mathrm{X} 1$ & 72 & 4.56 & 27.57 & 1135.16 & 15.7661 & 2.42218 & 5.867 \\
\hline Valid N & 72 & & & & & & \\
(listwise) & & & & & & & \\
\hline
\end{tabular}

Sumber : data diolah

1. Pengungkapan Corporate Social Responsibility (Y)

Berdasarkan hasil statistik deskriptif sesuai dengan tabel 1. menunjukan variable Pengungkapan Corporate Social Responsibility mempunyai nilai minimum sebesar 0,18 sedangkan nilai maksimumnya sebesar 0,54 dan mempunyai nilai rata - rata sebesar 0,3294 dengan penyimpangan rata - rata sebesar 0,08819 .

2. Sensitivitas Industri (X1)

Berdasarkan hasil statistik deskriptif sesuai dengan tabel 1. menunjukan variable Sensitivitas Industri memnunvai nilai minimum sehesar 000 sedanokan nilai maksimumnya sebesar 1,00 dan mempunyai nilai rata - rata sebesar 0,5417 dengan penyimpangan rata - rata sebesar 0,50176.

3. Ukuran Perusahaan (X2)

Berdasarkan hasil statistik deskriptif sesuai dengan tabel 1. menunjukan variable Ukuran Perusahaan mempunyai nilai minimum sebesar 4,56 sedangkan nilai maksimumnya sebesar 27,57 dan mempunyai nilai rata - rata sebesar 15,7661 dengan penyimpangan rata - rata sebesar 2,42218.

4. Kinerja Lingkungan (X3)

Berdasarkan hasil statistik deskriptif sesuai dengan tabel 1. menunjukan variable Kinerja Lingkungan mempunyai nilai minimum sehesar 20 sedangkan Page 119 
nilai maksimumnya sebesar 5,00 dan mempunyai penyimpangan rata - rata sebesar 0,50176 .

nilai rata - rata sebesar 3,2083 dengan

\section{Uji Normalitas}

Tabel 2.

One-Sample Kolmogorov-Smirnov Test

\begin{tabular}{|c|c|c|}
\hline & & $\begin{array}{c}\text { Unstandardize } \\
\text { d Residual }\end{array}$ \\
\hline $\mathrm{N}$ & & 72 \\
\hline \multirow[t]{2}{*}{ Normal Parameters ${ }^{\mathrm{a}, \mathrm{b}}$} & Mean & .0000000 \\
\hline & $\begin{array}{l}\text { Std. } \\
\text { Deviation }\end{array}$ & .07427932 \\
\hline \multirow{3}{*}{$\begin{array}{l}\text { Most Extreme } \\
\text { Differences }\end{array}$} & Absolute & .072 \\
\hline & Positive & .047 \\
\hline & Negative & -.072 \\
\hline \multicolumn{2}{|l|}{ Test Statistic } & .072 \\
\hline \multicolumn{2}{|l|}{ Asymp. Sig. (2-tailed) } & $200^{\mathrm{c}, \mathrm{d}}$ \\
\hline \multicolumn{3}{|c|}{ a. Test distribution is Normal. } \\
\hline \multicolumn{2}{|c|}{ b. Calculated from data. } & \\
\hline
\end{tabular}

Sumber : data diolah

Hasil uji Kolmogorov-Smirnov 0,05 maka dapat disimpulkan bahwa data menunjukkan bahwa nilai Asymp. Sig. (2-tailed) terdistribusi secara normal diterima. Oleh karena sebesar 0,200. Nilai ini lebih besar dari signifikan itu uji asumsi normalitas telah terpenuhi.

\section{Uji Multikolinearitas}

Tabel 3.

Coefficients $^{\mathrm{a}}$

\begin{tabular}{|c|c|c|c|c|c|c|c|c|}
\hline \multirow{2}{*}{\multicolumn{2}{|c|}{ Model }} & \multicolumn{2}{|c|}{$\begin{array}{l}\text { Unstandardized } \\
\text { Coefficients }\end{array}$} & \multirow{2}{*}{$\begin{array}{c}\text { Standardize } \\
\mathrm{d} \\
\text { Coefficients } \\
\\
\text { Beta } \\
\end{array}$} & \multirow[t]{2}{*}{$\mathrm{T}$} & \multirow[t]{2}{*}{ Sig. } & \multicolumn{2}{|c|}{$\begin{array}{l}\text { Collinearity } \\
\text { Statistics }\end{array}$} \\
\hline & & B & Std. Error & & & & $\begin{array}{l}\text { bleranc } \\
\text { e }\end{array}$ & VIF \\
\hline \multirow[t]{4}{*}{1} & (Constant) & .097 & .080 & & 1.216 & .228 & & \\
\hline & X3 & $\begin{array}{r}- \\
.048\end{array}$ & .018 & -.274 & -2.606 & .011 & .945 & 1.058 \\
\hline & $\mathrm{X} 2$ & .003 & .004 & .075 & .717 & .476 & .956 & 1.046 \\
\hline & $\mathrm{X} 1$ & .067 & .019 & .382 & 3.577 & .001 & .913 & 1.096 \\
\hline
\end{tabular}

a. Dependent Variable: Y

Sumber : data diolah

Tabel 3. menunjukkan bahwa untuk semua variabel independen yang digunakan Variabel Sensitivitas Industri, Ukuran Perusahaan, dan Kinerja Lingkungan memiliki nilai VIF yang dihasilkan kurang dari 10 dan nilai tolerance >
$10 \%(0,10)$ maka dapat disimpulkan bahwa tidak ada korelasi ganda (multikolinieritas) antar variabel independen. Oleh karena itu uji asumsi multikolinieritas telah terpenuhi. 
Tabel 4.

Model Summary ${ }^{\mathrm{b}}$

\begin{tabular}{llrrrr}
\hline Model & R & R Square & $\begin{array}{c}\text { Adjusted R } \\
\text { Square }\end{array}$ & $\begin{array}{c}\text { Std. Error of } \\
\text { the Estimate }\end{array}$ & $\begin{array}{c}\text { Durbin- } \\
\text { Watson }\end{array}$ \\
\hline 1 & $.539^{\text {a }}$ & .291 & .259 & .07590 & 1.745 \\
\hline
\end{tabular}

a. Predictors: (Constant), X3, X2, X1

b. Dependent Variable: Y

Sumber : data diolah

Tabel diatas menunjukan Nilai Durbin Watson (DW) sebesar 1,745. Berdasarkan tabel Durbin-Watson dengan N 72 dan banyak variabel bebas 3 diperoleh nilai upper boung (dU) sebesar
1,705 dan $4-\mathrm{dU}$ sebesar 2,295. Dapat dilihat nilai DW berada di antara batas atau upper boung (dU) dan 4- dU, dengan demikian $\mathrm{H}_{\mathrm{o}}$ diterima atau tidak terjadi Autokorelasi.

\section{Uji Heteroskedastisitas}

Tabel 5.

Coefficients $^{\mathrm{a}}$

\begin{tabular}{|c|c|c|c|c|c|c|}
\hline \multirow[b]{2}{*}{ Model } & & \multicolumn{2}{|c|}{$\begin{array}{l}\text { Unstandardized } \\
\text { Coefficients }\end{array}$} & \multirow{2}{*}{$\begin{array}{c}\begin{array}{c}\text { Standardize } \\
\mathrm{d} \\
\text { Coefficients }\end{array} \\
\text { Beta }\end{array}$} & \multirow[b]{2}{*}{$\mathrm{T}$} & \multirow[b]{2}{*}{ Sig. } \\
\hline & & $\mathrm{B}$ & Std. Error & & & \\
\hline \multirow[t]{4}{*}{1} & (Constant) & .118 & .039 & & 3.025 & .004 \\
\hline & X3 & .040 & .009 & -.488 & -4.463 & .051 \\
\hline & $\mathrm{X} 2$ & .001 & .002 & -.082 & -.753 & .454 \\
\hline & $\mathrm{X} 1$ & $\begin{array}{r}- \\
.004\end{array}$ & .009 & -.048 & -.435 & .665 \\
\hline
\end{tabular}

a. Dependent Variable: RES2

Sumber : data diolah

Jika model tersebut diuji secara parsial maka Tabel diatas menunjukkan bahwa semua variabel bebas yang digunakan pada penelitian yaitu Sensitivitas Industri, Ukuran Perusahaan, dan
Kinerja Lingkungan memiliki nilai signifikan lebih besar dari 0,05 sehingga dapat disimpulkan bahwa tidak terjadi heterokedasitas.

\section{Uji Regresi Linear Berganda}

Tabel 6.

Coefficients $^{\mathrm{a}}$

\begin{tabular}{|c|c|c|c|c|c|c|c|c|}
\hline & & $\begin{array}{r}\text { Unst } \\
\mathrm{Co}\end{array}$ & $\begin{array}{l}\text { ndardized } \\
\text { fficients }\end{array}$ & $\begin{array}{l}\text { Standardize } \\
\mathrm{d} \\
\text { Coefficients }\end{array}$ & $\mathrm{T}$ & Sig. & \multicolumn{2}{|c|}{$\begin{array}{c}\text { Collinearity } \\
\text { Statistics }\end{array}$} \\
\hline \multicolumn{2}{|c|}{ Model } & B & Std. Error & Beta & & & $\begin{array}{l}\text { pleranc } \\
\text { e }\end{array}$ & VIF \\
\hline \multirow[t]{4}{*}{1} & (Constant) & .097 & .080 & & 1.216 & .228 & & \\
\hline & X3 & $\begin{array}{r}- \\
.048\end{array}$ & .018 & -.274 & -2.606 & .011 & .945 & 1.058 \\
\hline & $\mathrm{X} 2$ & .003 & .004 & .075 & .717 & .476 & .956 & 1.046 \\
\hline & X1 & .067 & .019 & .382 & 3.577 & .001 & .913 & 1.096 \\
\hline
\end{tabular}

a. Dependent Variable: Y

Sumber : data diolah 
Berdasarkan tabel tersebut diperoleh model regresi berganda yang terbentuk pada penelitian ini adalah sebagai berikut :

$Y=0,097-0,067 \times 1+0,003 \times 2+0,048 \times 3$

Model ini memiliki interpretasi sebagai berikut :

1. Nilai konstanta sebesar 0,097, angka ini mempunyai arti bahwa jika tidak ada Sensitivitas Industri, Ukuran Perusahaan, dan Kinerja Lingkungan maka nilai konsisten dari CSR adalah sebesar 0,097.

2. Nilai koefisien Variabel Sensitivitas Industri sebesar $-0,048$ maka artinya apabila nilai
Sensitivitas Industri naik satu satuan maka CSR akan turun sebesar 0,048.

3. Nilai koefisien Variabel Ukuran Perusahaan sebesar 0,003 maka artinya apabila nilai Ukuran Perusahaan naik satu satuan maka CSR akan Naik sebesar 0,003.

4. Nilai koefisien Variabel Kinerja Lingkungan sebesar 0,067 maka artinya apabila nilai Kinerja Lingkungan naik satu satuan maka CSR kan Naik sebesar 0,067.

\section{Koefisien Determinasi $\left(\mathbf{R}^{2}\right)$ \\ Tabel 7.}

Model Summary ${ }^{\mathrm{b}}$

\begin{tabular}{lrrrrr}
\hline Model & $\mathrm{R}$ & R Square & $\begin{array}{c}\text { Adjusted R } \\
\text { Square }\end{array}$ & $\begin{array}{l}\text { Std. Error of } \\
\text { the Estimate }\end{array}$ & $\begin{array}{l}\text { Durbin- } \\
\text { Watson }\end{array}$ \\
\hline 1 & $.539^{\mathrm{a}}$ & .291 & .259 & .07590 & 1.745 \\
\hline
\end{tabular}

a. Predictors: (Constant), X3, X2, X1

b. Dependent Variable: Y

Analisis regresi yang digunakan adalah analisis regresi berganda sehingga koefisien determinasi yang digunakan adalah Adjusted R square (koefisien determinasi terkoreksi). Nilai koefisien yang diperoleh adalah sebesar 0,259. Nilai determinasinya menjadi $0,259 \times 100 \%=$
25,9\%. Hal ini mengindikasikan bahwa CSR dijelaskan 25,9\% oleh Variabel Sensitivitas Industri, Ukuran Perusahaan, dan CSR sisanya $74,1 \%$ dipengaruhi oleh faktor-faktor atau variabel-variabel lain yang tidak dimasukan dalam model penelitian.

\begin{tabular}{|c|c|c|c|c|c|c|}
\hline \multicolumn{7}{|c|}{$\begin{array}{c}\text { Uji Signifikan Simultan (Uji F) } \\
\text { Tabel 8. } \\
\text { ANOVA }^{\mathrm{a}}\end{array}$} \\
\hline Model & & $\begin{array}{c}\text { Sum of } \\
\text { Squares }\end{array}$ & Df & $\begin{array}{l}\text { Mean } \\
\text { Square }\end{array}$ & $\mathrm{F}$ & Sig. \\
\hline \multirow[t]{3}{*}{1} & $\begin{array}{l}\text { Regressio } \\
\mathrm{n}\end{array}$ & .160 & 3 & .053 & 9.283 & $.000^{\mathrm{b}}$ \\
\hline & Residual & .392 & 68 & .006 & & \\
\hline & Total & .552 & 71 & & & \\
\hline \multicolumn{7}{|c|}{ a. Dependent Variable: Y } \\
\hline \multicolumn{7}{|c|}{ b. Predictors: (Constant), X3, X2, X1 } \\
\hline
\end{tabular}

Pada Tabel tersebut dapat dilihat nilai signifikan sebesar 0,000 atau $<0,05$ maka menunjukan bahwa variabel independen yang digunakan yaitu Kinerja Lingkungan ,Sensitivitas Industri, dan Ukuran Perusahaan, berpengaruh signifikan secara simultan terhadap CSR. Ini berarti hasil nilai signifikan sebesar 0,000 atau < 0,05 maka dapat disimpulkan model regresi layak digunakan. 
Tabel 9.

Coefficients $^{\mathrm{a}}$

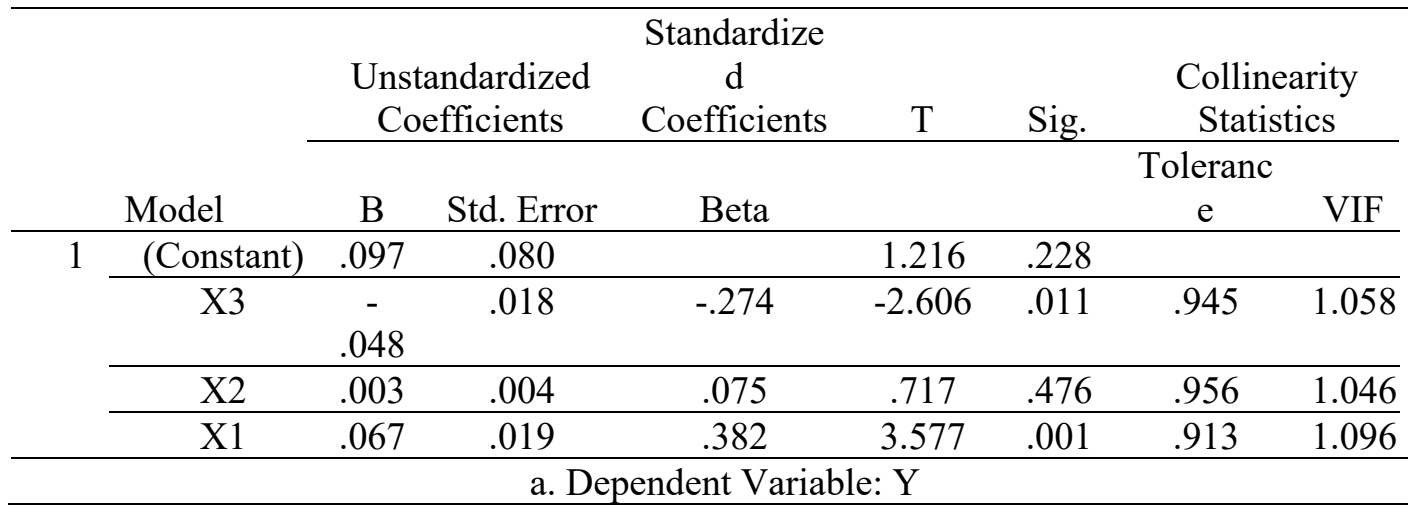

Adapun hal-hal yang dapat diinterpretasikan dari tabel tersebut adalah sebagai berikut:

1. Variabel Kinerja Lingkungan

Setelah diuji secara parsial dengan menggunakan uji t, diperoleh nilai sig. sebesar 0,001 lebih kecil dari 0,05 sehingga dapat disimpulkan bahwa variabel Kinerja Lingkungan memiliki pengaruh positif dan signifikan terhadap CSR. Hal ini berarti hipotesis ketiga diterima.

2. Variabel Sensitivitas Industri

Setelah diuji secara parsial dengan menggunakan uji t, diperoleh nilai sig. sebesar 0,011 lebih kecil

\section{Pembahasan Hasil Penelitian}

1. Pengaruh Kinerja Lingkungan terhadap CSR pada Perusahaan Manufaktur di Bursa Efek Indonesia

Berdasarkan hasil penelitian bahwa kinerja lingkungan berpengaruh terhadap CSR. Berdasarkan teori legitimasi menjelaskan hubungan antara masyarakat dengan perusahaan dimana masyarakat memberikan penghargaan apabila perusahaan melaksanakan kegiatan operasinya dengan baik dan diimbangi dengan tindakan sosial sehingga akan berpengaruh terhadap keberlangsungan hidup perusahaan. Adanya penghargaan ini berarti kegiatan operasi perusahaan tidak berlawanan dengan UU karena menjalankan prinsip ramah lingkungan.

Hasil penelitian ini mendukung penelitian Sari et al. (2017) dan (Handayati, 2017) yang menyatakan bahwa PROPER mendorong perusahaan untuk selalu melaksanakan peningkatan kinerja lingkungan perusahaan dengan mengungkapkan segala bentuk aktivitas mengenai tanggung jawab sosial dan lingkungan yang lebih luas, sehingga apabila telah berjalan sesuai dengan peraturan yang berlaku maka akan diberikan penghargaan oleh pemerintah sesuai dengan luas pengungkapan dan dari 0,05 sehingga dapat disimpulkan bahwa variabel Sensitivitas Industri berpengaruh positif dan signifikan terhadap CSR. Hal ini berarti hipotesis pertama diterima.

3. Variabel Ukuran Perusahaan

Setelah diuji secara parsial dengan menggunakan uji t, diperoleh nilai sig. sebesar 0,476 lebih besar dari 0,05 sehingga dapat disimpulkan bahwa variabel Ukuran Perusahaan berpengaruh negatif terhadap CSR. Hal ini berarti hipotesis kedua ditolak.

dampak dari tanggung jawab yang diterapkan dan penghargaan ini dapat memberikan dampak positif bagi keberlanjutan perusahaan. Selain itu, bagi perusahaan yang kinerja lingkungannya belum termasuk kategori baik akan lebih termotivasi untuk melakukan pengungkapan tanggung jawab sosial.

2. Pengaruh Sensitivitas Industri terhadap CSR pada Perusahaan Manufaktur di Bursa Efek Indonesia

Hasil penelitian diketui bahwa sensitivitas Industri berpengaruh terhadap CSR. Hasil penelitian ini mendukung teori legitimasi menyatakan bahwa semakin tinggi tingkat sensitivitas industri maka semakin tinggi legitimasi yang diberikan masyarakat terhadap perusahaan karena perusahaan melakukan pengungkapan tanggung jawab sosial yang luas.

Hasil penelitian ini sesuai dengan Widiastuti et al., (2018) dan Susilowati, Zulfa, \& Hartono, (2018) yang menemukan bahwa Sensitivitas Industri yang diproksikan dengan perusahaan high profile akan lebih banyak mengungkapkan informasi sosial karena aktivitas operasinya bersinggungan dengan lingkungan dan dianggap memiliki dampak yang 
signifikan terhadap lingkungan sehingga mendapatkan banyak perhatian dari masyarakat.

3. Pengaruh Ukuran Perusahaan terhadap CSR pada Perusahaan Manufaktur di Bursa Efek Indonesia

Berdasarkan hasil penelitian bahwa ukuran Perusahaan tidak berpengaruh terhadap CSR. Hasil penelitian ini tidak mendukung teori legitimasi bahwa perusahaan besar melakukan aktivitas yang lebih banyak dibandingkan perusahaan kecil sehingga memiliki pengaruh lebih besar terhadap masyarakat dan investor yang pedulu dengan program sosial dalam laporan tahunan perusahaan. Akan tetapi hasil ini didukung dengan adanya adanya regulasi pemerintah yaitu Undang-undang No.40 tahun 2007 yang mengatur tentang tanggung jawab sosial dan lingkungan yaitu baik perusahaan besar maupun kecil memiliki program pengungkapan sosial setiap tahunnya. Jadi besar kecilnya perusahaan tidak mempengaruhi pengungkapan tanggung jawab sosial karena semua ukuran perusahaan dipandang sama.

Hasil penelitian ini serupa dengan penelitian Harsono et al. (2012) dan Sari et al. (2017) yang menyatakan bahwa perusahaan besar belum memandang keefektifitasan pengungkapan tanggung jawab. Selain itu, keputusan pengungkapan tanggung jawab sosial bukan berdasarkan banyaknya aktivitas operasi perusahaan tetapi bersarkan faktor biaya karena mempublikasikan laporan pertanggungjawaban sosial bukanlah hal yang murah.

\section{SIMPULAN DAN SARAN}

\section{Simpulan}

Berdasarkan hasil analisis dan pembahasan mengenai Pengaruh Sensitivitas Industri, Ukuran
Perusahaan, dan Kinerja Lingkungan terhadap Corporate Social Responsibility pada Perusahan Manufaktur yang terdaftar di Bursa Efek Indonesia, maka dapat ditarik kesimpulan sebagai berikut :

1. Variabel Kinerja Lingkungan mempunyai pengaruh yang positif dan signifikan terhadap CSR pada Perusahaan Manufaktur yang terdaftar di BEI 2. Variabel Ukuran Perusahaan mempunyai pengaruh yang negatif terhadap CSR pada Perusahaan Manufaktur yang terdaftar di BEI, hal ini dapat dilihat dari hasil uji t yang menunjukkan bahwa nilai signifikan 0,476 lebih besar dari 0,05.

3. Variabel Sensitivitas Industri mempunyai pengaruh yang positif dan signifikan terhadap CSR pada Perusahaan Manufaktur yang terdaftar di BEIVariabel Ukuran Perusahaan mempunyai pengaruh yang negatif terhadap CSR pada Perusahaan Manufaktur yang terdaftar di BEI,

\section{Saran}

1. Penilaian luas pengungkapkan CSR bersumber dari laporan keuangan dan laporan tahunan perusahaan. Apabila pada lapran keuangan dan laporan tahunan perusahaan tidak ada atau tidak terdapat informasi eksplisit dari pengungkapan maka penilaian dilakukan secara subyektif, mengakibatkan hasil dan pandangan berbeda dari penelitian sebelumnya. Oleh karena itu, penelitian berikutnya sebaiknya menggunakan panduan laporan keberlanjutan dalam pengungkapan CSR dan dibutuhkannya kesadaran perusahaan agar mempublikasikan pengungkapan sosial sebagai tanggung jawab sosial mereka.

2. Penelitian selanjutnya dapat memperluas objek penelitian yang tidak terbatas dengan perusahaan manufaktur saja dan dapat menambah jumlah sampel yang digunakan

\section{DAFTAR PUSTAKA}

Anggraini, F. R. R. (2006). Pengungkapan Informasi Sosial dan Faktor-Faktor yang Mempengaruhi Pengungkapan Informasi Sosial dalam Laporan Keuangan Tahunan (The Disclosure of Social Information and Factors Affecting the Disclosure of Social Information in Annual Report). Simposium Nasional Akuntansi IX Padang, 21 23-26. https://doi.org/10.1177/0007650314564783

Hadi, N. (2011). Corporate Social Responsibility edisi Pertama: Graha Ilmu. Yogyakarta. Kusumawati, Citra.

Handayati, P. (2017). ANALISIS KINERJA LINGKUNGAN DAN MEKANISME GCG TERHADAP, 4(1), 58-68.

Harsono, L., Handoko, J., \& Fransisca, I. (2012). Pengaruh Tipe Industri, Ukuran Perusahaan, dan Kepemilikan Manajerial Terhadap Tingkat Pengungkapkan Tanggung Jawab Sosial. Jurnal Akuntansi Kontemporer, 4(1).

Mulyadi, M. S., \& Anwar, Y. (2012). Impact of corporate

social responsibility toward firm value and profitability. The Business Review, Cambridge, 2(January 2012), 316-322.

Nur, M., \& Priantinah, D. (2012). Analisis Faktor - Faktor Yang Mempengaruhi Pengungkapan Corporate Social Responsiblity di Indonesia. Jurnal Nominal, I(I).

Sari, T. S. I., Yuliandari, W. S., \& Nurbaiti, A. (2017). Pengaruh Kinerja Keuangan, Ukuran Perusahaan, dan Kinerja Lingkungan Terhadap Penngungkapan Corporate Social Responsibility. ISSN-2252-3936. Retrieved from repository.widyatama.ac.id

Sukasih, A., \& Sugiyanto, E. (2017). Pengaruh Struktur Good Corporate Governance dan Kinerja Lingkungan Terhadap Pengungkapan Corporate Social Responsibility. Riset Akuntansi Dan Keuangan Indonesia, 2(2), 121-131.

Suratno, I. B., Darsono, D., \& Mutmainah, S. (2007). 
Pengaruh Environmental Performance Terhadap Environmental Disclosure dan Economic Performance (Studi Empiris pada Perusahaan Manufaktur yang terdaftar di BEJ Periode 2001-2004). The Indonesian Journal of Accounting Research, 10(2).

Susilowati, F., Zulfa, K., \& Hartono, A. (2018). Pengaruh Ukuran Perusahaan, Profitabilitas, Leverage, Tipe Industri, dan Ukuran Dewan Komisaris Terhadap Corporate Social Responsibility Disclosure. Jurnal Ekonomi, Manajemen Dan Akuntansi, 2(1), 15-25.

Widiastuti, H., Utami, E. R., \& Handoko, R. (2018). Pengaruh Ukuran Perusahaan, Tipe Industri, Growth, dan Media Exposure Terhadap Pengungkapan Tanggung Jawab Sosial Perusahaan. Riset Akuntansi Dan Keuangan Indonesia, 3(25), 107-117. 